\title{
Erratum to: Diagnostic Ultrasound Features and Outcome of Restrictive Foramen Ovale in Fetuses With Structurally Normal Hearts
}

\author{
Orhan Uzun · Kadir Babaoglu • Yusuf I. Ayhan - Marsham Moselhi • \\ Fran Rushworth · Sue Morris · Bryan Beattie · Jarmilla Wiener • \\ Michael J. Lewis
}

Published online: 20 May 2014

(C) Springer Science+Business Media New York 2014

\section{Erratum to: Pediatr Cardiol}

\section{DOI 10.1007/s00246-014-0879-5}

The original version of this article unfortunately contained few mistakes. The errors are corrected as given below:

1. In the abstract, the numbers of deaths were typed incorrectly as "...7 infants died." The correct number should have been "....two infants died."

2. In Table 2, the range and Mean \pm SD parameters of the isthmus-to-ductus ratio were erroneously typed as:

\begin{tabular}{lllll}
\hline Aortic isthmus & Patients & $\%$ & Range & Mean \pm SD \\
\hline $\begin{array}{l}\text { Isthmus-to-ductus } \\
\text { ratio }<0.74\end{array}$ & 17 & 74 & $1.02-2.8$ & $1.69 \pm 0.38$ \\
\hline
\end{tabular}

The online version of the original article can be found under doi: 10 . 1007/s00246-014-0879-5.

\section{O. Uzun $(\bowtie)$}

Department of Paediatric Cardiology, University Hospital of Wales, Cardiff CF14 4XW, Wales, UK

\section{K. Babaoglu}

Department of Paediatric Cardiology, Kocaeli University

Medical Faculty, Izmit, Turkey

\section{Y. I. Ayhan}

Department of Paediatric Cardiology, Goztepe Hospital, Medeniyet University, Istanbul, Turkey

\section{Moselhi}

Department of Obstetrics and Gynaecology, Singleton Hospital,

Swansea, Wales, UK
Correct parameters should have been:

\begin{tabular}{lllll}
\hline Aortic isthmus & Patients & $\%$ & Range & Mean \pm SD \\
\hline $\begin{array}{c}\text { Isthmus-to-ductus } \\
\text { ratio }<0.74\end{array}$ & 17 & 74 & $0.46-1.0$ & $0.63 \pm 0.13$ \\
\hline
\end{tabular}

\footnotetext{
F. Rushworth

Department of Obstetrics and Gynaecology, Princess of Wales Hospital, Bridgend, Wales, UK

\section{S. Morris}

Department of Radiology, University Hospital of Wales, Cardiff, Wales, UK

B. Beattie $\cdot$ J. Wiener

Department of Obstetrics and Gynaecology, University Hospital of Wales, Cardiff, Wales, UK

M. J. Lewis

College of Engineering, Swansea University, Swansea, Wales, UK
} 